\title{
Occurrence and Timing of Complications of Crown-Fractures in Permanent Incisors: A Randomized Clinical Trial
}

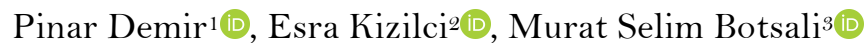

\begin{abstract}
'Department of Pediatric Dentistry, Faculty of Dentistry, Inonu University, Malatya, Turkey.
'Department of Pediatric Dentistry, Faculty of Dentistry, Erciyes University, Kayseri, Turkey.

${ }^{3}$ Department of Pediatric Dentistry, Faculty of Dentistry, Selcuk University, Konya, Turkey.
\end{abstract}

Correspondence: Dr. Pinar Demir, Department of Pediatric Dentistry, Faculty of Dentistry, Inonu University, Elazig yolu 10. km Malatya 44380, Turkey. E-mail: pinardemir101@hotmail.com

Academic Editor: Catarina Ribeiro Barros de Alencar

Received: 04 December 2020 / Review: 27 February 2021 / Accepted: 16 March 2021

How to cite: Demir P, Kizilci E, Botsali MS. Occurrence and timing of complications of crown-fractures in permanent
incisors: a randomized clinical trial. Pesqui Bras Odontopediatria Clín Integr. 2021; $21: e 0254$.
https://doi.org/10.1590/pboci.2021.116

\begin{abstract}
Objective: To investigate the complications of crown fractures that might occur in different follow-up periods. Material and Methods: Individuals within the 6-13 age range with crown fracture and consulted to University Hospital were included in the study. Patients were randomly divided into three groups by block randomization method and evaluated clinical and radiographically for complications at the 6,8 weeks, and $6,12,24$ months. The crown of the tooth was divided into 9 equal squares and 6 classes of fracture types were created. Complications and their frequencies were evaluated based on the post-traumatic substance losses in these illustrated fracture types. Results: The incidence of complications was $28.9 \%$ at 6 months, $51.3 \%$ at 1 year, and $63.9 \%$ at 2 years. Class 4 fractures had the highest probability of complications $(32.4 \%)$ and the development of pulp necrosis $(40.3 \%)$. It was detected that the complications such as pulp necrosis $(21.6 \%)$ can be frequently observed in the 2 nd year or later periods of crown fractures. Conclusion: In addition to current regular checks, periodic follow-up of crown fracture should be extended to reflect current findings. Dentists, patients, and their parents must be made conscious of the importance of the treatment and follow-ups of crown fracture.
\end{abstract}

Keywords: Tooth Injuries; Postoperative Complications; Dental Pulp Necrosis; Dentition, Permanent. 


\section{Introduction}

Although the incidence of dental caries and periodontal problems in children decreases with the improvement of preventive dentistry, epidemiological studies show that TDI is still a common problem that cannot be controlled [1-6]. One of the most important reasons for emergency dental treatment applications is dental injuries. Studies show that $3-80 \%$ of emergency dental treatments are due to dental injuries [7-12]. This rate has been reported as $27 \%$ in the USA, $23 \%$ in the UK and $31 \%$ in Israel $[7,8,13]$. A study conducted by Odabaş et al. [14] in Turkey in 2012 suggests that $10.1 \%$ of the patients are referred for emergency because of the trauma.

Many studies report that crown fractures are the most common type of trauma, but studies rather involve etiology, epidemiology and incidence $[1,4,15,16]$. Indeed, there are a limited number of studies about complications and treatment of crown fractures [17,18]. This study aims to evaluate the etiology of permanent incisors with crown fractures, to determine the procedures and success of treatment. The purpose of the current study is to examine the complications that can be seen in the 6-month, 1-year and 2-year (and above) follow-up periods of crown fractures, which have an important place among the dental problems of childhood and adolescence.

\section{Material and Methods}

Ethical Clearance, Study Design, and Sampling

The ethics committee approval was obtained (Decision No: 2014/237). When it examined the trauma patients who came to this clinic between 2010 and 2013, the incidence of trauma in this clinic was found to be $1.04 \%$. The total number of trauma patients who refer to this clinic was 237 , the number of teeth was 406 , and the number of teeth with crown fracture was 249 (61.3\%). It's calculated that there should be at least 67 teeth in each group taking $\alpha=0.05,1-\beta$ (power)=0.80 during the power analysis performed based on this information and the previous studies $[1,5,14]$. Considering the patient losses that may occur during the study, 83 teeth were included in each group in the study. In this prospective clinical study, patients were distributed to groups by block randomization method based on the order of arrival. Until interventions were assigned, patient records were given numbers and shared in sequentially numbered containers.

6-13 years old patients who applied to the university's dental hospital due to traumatic tooth injury and who had crown-fractured permanent incisor(s) were included in the study. Patients with any systemic disease, mental problems, or caries in the relevant tooth before trauma were excluded from the study. Patients with a gingival and periodontal index of $2 / 3$ or any periodontal problem were also excluded from the study because it might affect the healing process.

\section{Data Collection}

All the patient forms/records keeping and treatment procedures were performed by one postgraduate pediatric dentistry Ph.D. student and controlled by two specialist consultants for each patient separately. Medical and social history was taken from the parents of the children and trauma record forms were filled out. The families were informed about the study to be carried, and the informed consent forms were signed. Study data and patient forms were stored in the department archive. The detailed diagnoses and treatment protocols (including radiographs, operation details and time, etc.) of the patients were recorded in detail in the database program, which can only be viewed by the active doctors of the hospital. After emergency treatment, each 
patient was offered a recall visit at the appropriate interval according to the diagnosis at the Department of Pediatric Dentistry.

Diagnostic and treatment protocols were made upon clinical and radiographic evaluations using the well-accepted classification system by Andreasen and Andreasen [19]. Every one of the referred crown fractures was distinguished as cases with no direct pulp exposure (uncomplicated crown fracture), and cases with pulp exposure (complicated crown fracture). The restorative management of all crown fractures followed the latest IADT clinical guidelines.

The management of uncomplicated crown fractures requires two possible treatments were employed. If the fractured tooth fragment was saved, then the adhesive reattachment of the fragment was the first treatment procedure of choice. Secondly, if the fragment was lost, a direct composite restoration was applied. In complicated crown fracture management, it was decided according to the time of presentation of the patient and the size/location of the pulp expose. Cvek amputation was applied to patients who were admitted in the early period. Root canal treatment was applied to patients who came in the late period and were diagnosed with necrosis. MTA plugs were used in teeth with an open apex.

The patients were divided into 3 groups by follow-up periods of 6 months, 1 year, and 2 years, and each group was individually examined in terms of complications. The patients treated within the scope of the study were evaluated as follows:

- 6 Month Group: Evaluated clinically and radiographically at the 6, 8 weeks and 6 months.

- 1 Year Group: Evaluated for the 1st year in addition to all controls of the 6-month group.

- 2 Year Group: Evaluated for the 2nd year in addition to all controls of the 1st year group.

In the case of luxation, the relevant patients were also invited to clinical and radiographic controls at weeks 2 and 4 in addition to their respective intragroup controls. Control data were evaluated clinically and radiographically in terms of possible complications. In the current study, cases with a problem in any of the parameters examined clinically or radiographically were recorded as positive complications.

In this study, patients who applied within the first three days following the trauma were designated as the "early treatment" group and patients who applied after three days as the "delayed treatment" group [20,21]. In the clinical evaluation, the patient's complaints, spontaneous pain, hot-cold sensitivity, percussion/palpation sensitivity, and the presence of fistula were evaluated. While the traumatized tooth was evaluated by both mobility and electric pulp test, the same tests were applied to its symmetry and the results were recorded.

Pulp prognosis was categorized as vital, necrotic and pulp canal obliteration based on previous studies [22,23] (Table 1). The tooth was recorded as "necrosis" in the presence of two of the symptoms clinically and in the presence of apical radiolucency and/or inflammatory resorption on radiography. If spontaneous pain or swelling occurred, the tooth was considered as "necrosis" [22,23].

Table 1. Criteria for final pulp prognosis from Robertson et al. [22].

\begin{tabular}{lcc}
\hline \multicolumn{1}{c}{ Diagnosis } & Clinical Criteria & Radiographic Criteria \\
\hline Pulp Survival (PS) & Normal color & No pathologic changes \\
& Normal electrometric pulp testing (EPT) & Apical radiolucency \\
Pulp Necrosis (PN) & Discoloration & Inflammatory resorption \\
& Negative EPT & Constriction of pulp canal \\
\hline
\end{tabular}


Post-traumatic substance loss and the size of restoration were categorized based on Ravn's [24] classification. The crown of the tooth was divided into 9 equal squares and 6 classes of fracture types were created (Figure 1). Microsoft Paint software (Microsoft Corporation, ABD) was used to create illustrations. Afterward, the teeth were divided into 2 groups to obtain statistical data:

* Group 1: Substance losses of 3 units or less (Class 1,2,3),

* Group 2: Substance losses of more than 3 units (Class 4,5,6).

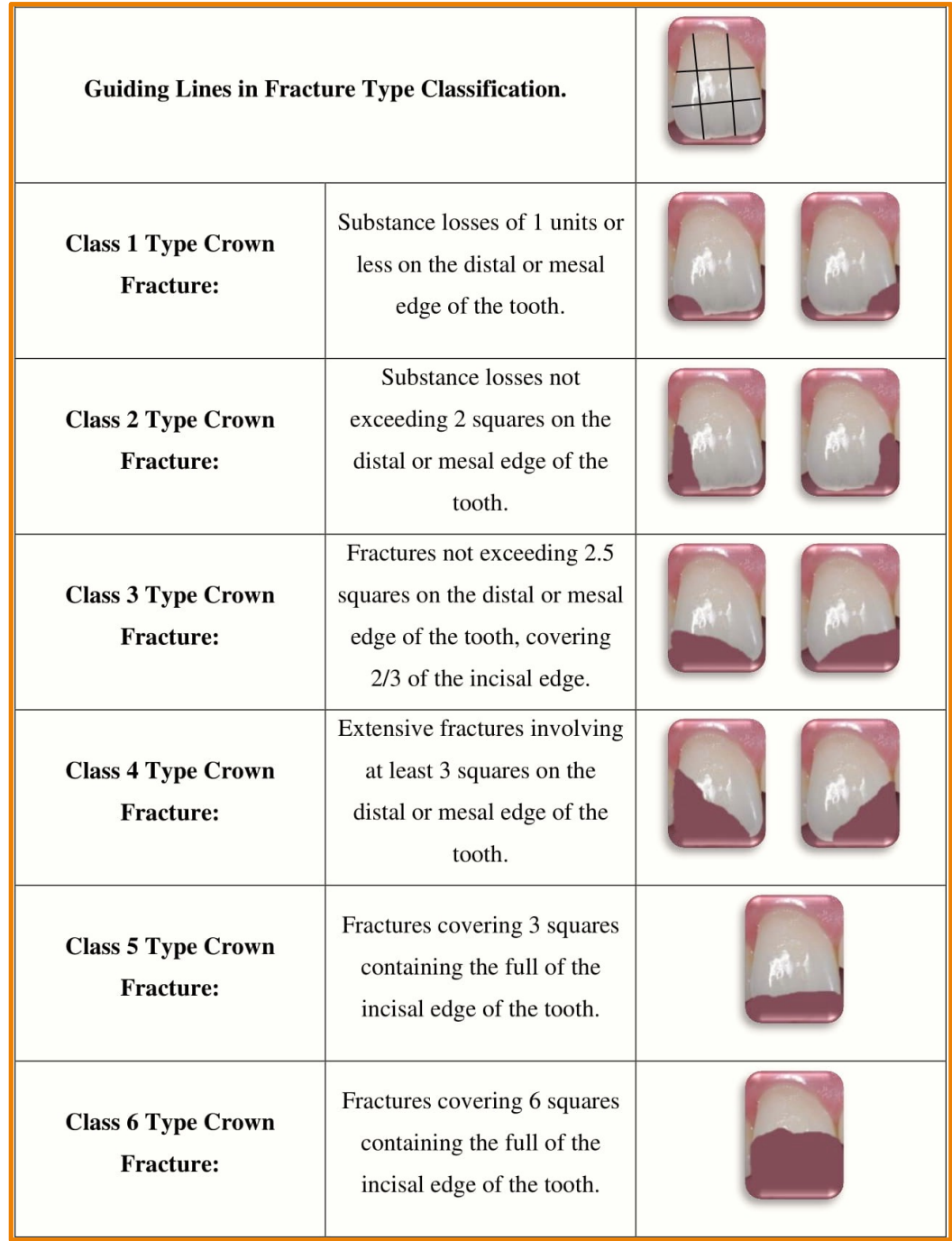

Figure 1. The crown fracture types.

Each patient's periapical radiograph was taken and examined. In the radiographs taken, apical radiolucency was recorded in the case of an increase/decrease in the lamina dura width. Pulp canal obliteration, internal/external root resorption, and presence of ankylosis were evaluated. Root development was controlled by comparing with patient's radiographs taken in previous sessions and symmetrical nontraumatic tooth. Root development level was classified as "Open" if there was an opening larger than $1 \mathrm{~mm}$ at the root tip, or "Closed" in the case of root tips less than $1 \mathrm{~mm}$ or closed [19,23,25]. During the controls, root development status was classified as "root development stopped", "root development ongoing" or "root development completed". The study was terminated at the end of the 2-year controls for data collection and evaluation, but the routine patient follow-up was continued as required by the treatment procedure. 


\section{Data Analysis}

Statistical evaluation of the data obtained during the study was performed using IBM SPSS Statistics 17 (IBM SPSS, Armonk, NY, USA). In the study, quantitative data was presented in mean and standard deviation and qualitative data was presented in numbers and percentages. Since the study used qualitative data, Pearson's Chi-Square and Fisher's Exact Chi-Square Test were used. A p-value <0.05 was considered statistically significant.

\section{Results}

This study involved 249 teeth of 157 children, 109 boys (69.4\%), and 48 girls (30.6\%). Three patients ( 5 teeth) were excluded from the study because they skipped routine controls. The patients were aged between 6 and 13 years old and the average age was $9.47 \pm 1.69$ years. $66.8 \%$ of the teeth involved in this study were diagnosed with an uncomplicated crown fracture, and $33.2 \%$ were diagnosed with complicated crown fractures. In this study, it was determined that $34.4 \%$ of the children were taken to a dentist on the same day; and $61.8 \%$ were taken to a dentist in the first 72 hours (early stage). 119 of the 244 teeth included in this study were in the "early treatment" group, and 125 in the "late treatment" group. The rate of recurrent TDI among the patients was found to be $12.3 \%$.

When the distribution of teeth according to substance loss was examined, $41.3 \%$ of the teeth were found to involve class 3 fractures. $26.6 \%$ of the teeth were found to involve class 4 fractures, $18 \%$ class $6,7.3 \%$ class 5, 4\% class 1 , and $2.4 \%$ class 2 fractures. In the current study, the rate of complications was $28.9 \%$ at month $6,51.3 \%$ in year 1 , and $63.9 \%$ in year 2 . The most common complication is pulp necrosis, with $88.8 \%$. In addition, $54.7 \%$ of 117 teeth with complications suffered filling loss, 3.2\% coronal discoloration, $2.5 \%$ periapical lesion, $1.7 \%$ RCT failure, $0.8 \%$ tooth loss. When the results were evaluated according to substance loss, class 4 fractures were determined as the ones with the highest probability of complications with a rate of $32.4 \%$. Class 3 fractures ranked second with $29 \%$, while the probability of developing complications was lowest in class 2 fractures with the lowest rate of $3.4 \%$.

It was found that the rate of complications in complicated fractures increased statistically significantly in 1-year controls, and more complications were observed in complicated fractures in all follow-up periods. It was found that, in the cases where the crown fracture is accompanied by luxation injury, complication rates were $50 \%$ at month $6,66 \%$ in year 1 , and $85 \%$ in year 2 . It has been determined that luxation statistically significantly increases the incidence of complications in all follow-up periods $(p<0.05)$. It was found that early or late treatment after trauma did not affect the incidence of complications ( $\mathrm{p}>0.05)$.

Statistically significant results were obtained only in the 1-year period in fractures with more than 3 units of substance loss (Table 2).

Table 2. Effect of substance loss on complication rate.

\begin{tabular}{|c|c|c|c|c|c|c|c|c|c|c|}
\hline \multirow{3}{*}{ Substance Loss } & & \multicolumn{9}{|c|}{ Complication } \\
\hline & & \multicolumn{3}{|c|}{6 Month } & \multicolumn{3}{|c|}{1 Year } & \multicolumn{3}{|c|}{2 Year or More } \\
\hline & & Yes & No & Total & Yes & No & Total & Yes & No & Total \\
\hline \multirow[t]{2}{*}{ Less than 3 units } & $\mathrm{N}$ & 11 & 34 & 45 & 11 & 25 & 36 & 21 & 15 & 36 \\
\hline & $\%$ & 24.4 & 75.5 & 100.0 & 30.6 & 69.4 & 100.0 & 58.3 & 41.6 & 100.0 \\
\hline \multirow[t]{2}{*}{ More than 3 units } & $\mathrm{N}$ & 13 & 25 & 38 & 29 & 13 & 42 & 32 & 15 & 47 \\
\hline & $\%$ & 34.2 & 65.7 & 100.0 & 69.0 & 31.0 & 100.0 & 68.0 & 31.9 & 100.0 \\
\hline \multirow[t]{2}{*}{ Total } & $\mathrm{N}$ & 24 & 59 & 83 & 40 & 38 & 78 & 53 & 30 & 83 \\
\hline & $\%$ & 28.9 & 71.1 & 100.0 & 51.3 & 48.7 & 100.0 & 63.9 & 36.1 & 100.0 \\
\hline p-value & & & 0.328 & & & $0.001 *$ & & & 0.359 & \\
\hline
\end{tabular}


However, in all follow-up periods, if the loss of the substance was more than 3 units, the probability of complications was increased. The rate of complication development in traumatic teeth with open apex was found statistically significantly lower in the 6-month period (16.1\%). Less complication was observed in teeth with the open apex in all periods (Table 3 ).

Table 3. Effect of root maturation on complication rate.

\begin{tabular}{|c|c|c|c|c|c|c|c|c|c|c|}
\hline \multirow{3}{*}{\multicolumn{2}{|c|}{ Root Maturation }} & \multicolumn{9}{|c|}{ Complication } \\
\hline & & \multicolumn{3}{|c|}{6 Month } & \multicolumn{3}{|c|}{1 Year } & \multicolumn{3}{|c|}{2 Year or More } \\
\hline & & Yes & No & Total & Yes & No & Total & Yes & No & Total \\
\hline \multirow[t]{2}{*}{ Open } & $\mathrm{N}$ & 5 & 26 & 31 & 17 & 22 & 39 & 20 & 17 & 37 \\
\hline & $\%$ & 16.1 & 83.8 & 100.0 & 43.6 & 56.4 & 100.0 & 54.0 & 45.9 & 100.0 \\
\hline \multirow[t]{2}{*}{ Closed } & $\mathrm{N}$ & 19 & 33 & 52 & 23 & 16 & 39 & 33 & 13 & 46 \\
\hline & $\%$ & 36.5 & 63.3 & 100.0 & 58.9 & 41.0 & 100.0 & 71.7 & 28.2 & 100.0 \\
\hline \multirow[t]{2}{*}{ Total } & $\mathrm{N}$ & 24 & 59 & 83 & 40 & 38 & 78 & 53 & 30 & 83 \\
\hline & $\%$ & 28.9 & 71.1 & 100.0 & 51.3 & 48.7 & 100.0 & 63.9 & 36.1 & 100.0 \\
\hline $\mathrm{p}$-value & & & $0.047 *$ & & & 0.365 & & & 0.096 & \\
\hline
\end{tabular}

*Statistically Significant.

Parameters affecting pulp necrosis, which is the most common complication, were also evaluated. A complicated crown fracture that involves the pulp, increases the likelihood of developing pulp necrosis. There is a statistically significant difference in the findings in each period $(\mathrm{p}<0.001)$. When the relationship between the occurrence of luxation and pulp necrosis was evaluated; pulp necrosis was found in the patients with luxation by $54 \%$ at month $6,72 \%$ at year 1 , and $66 \%$ at year 2 . It was found that the luxation injury that accompanies crown fracture causes a statistically significant increase in the incidence of pulp necrosis in all groups $(\mathrm{p}<0.05)$. Pulp necrosis was observed in the teeth with a substance loss above 3 units by $47 \%$ in month $6,64 \%$ in year 1 , and $61 \%$ in year 2 . These rates were found statistically significant in all groups (Table 4 ) $(p<0.05)$. The development status of pulp necrosis was found highest in class 4 fractures with a rate of $40.3 \%$. Pulp necrosis was observed by $26.9 \%$ in class 6 fractures, while this rate was $1.9 \%$ in class 2 fractures.

Table 4. Effect of substance loss on pulp necrosis.

\begin{tabular}{|c|c|c|c|c|c|c|c|c|c|c|}
\hline \multirow{3}{*}{ Substance Loss } & & \multicolumn{9}{|c|}{ Pulp Necrosis } \\
\hline & & \multicolumn{3}{|c|}{6 Month } & \multicolumn{3}{|c|}{1 Year } & \multicolumn{3}{|c|}{2 Year or More } \\
\hline & & Yes & No & Total & Yes & No & Total & Yes & No & Total \\
\hline \multirow[t]{2}{*}{ Less than 3 units } & $\mathrm{N}$ & 10 & 35 & 45 & 10 & 26 & 36 & 10 & 26 & 36 \\
\hline & $\%$ & 22.2 & 77.7 & 100.0 & 27.8 & 72.2 & 100.0 & 27.7 & 72.2 & 100.0 \\
\hline \multirow[t]{2}{*}{ More than 3 units } & $\mathrm{N}$ & 18 & 20 & 38 & 27 & 15 & 42 & 29 & 18 & 47 \\
\hline & $\%$ & 47.3 & 52.6 & 100.0 & 64.3 & 35.7 & 100.0 & 61.7 & 38.2 & 100.0 \\
\hline \multirow[t]{2}{*}{ Total } & $\mathrm{N}$ & 28 & 55 & 83 & 37 & 41 & 78 & 39 & 44 & 83 \\
\hline & $\%$ & 33.7 & 66.3 & 100.0 & 47.4 & 52.6 & 100.0 & 47.0 & 53 & 100.0 \\
\hline p-value & & & $0.016^{*}$ & & & $0.001 *$ & & & $0.002 *$ & \\
\hline
\end{tabular}

*Statistically Significant.

\section{Discussion}

In addition to subjective symptoms such as spontaneous pain, hot-cold sensitivity, percussion/palpation sensitivity in traumatized teeth, complications such as pulp necrosis, fistula formation, pulp degeneration, root resorption, marginal alveolar bone loss, and mobility can also be observed [19]. In the literature, the post-TDI incidence rate of complications has been reported at rates ranging from $23 \%$ to $84 \%$ [26-28]. Sandalli et al. [26] reported a post-TDI complication development rate of 23\%. In the current study, this rate was calculated as $47.9 \%$ in accordance with the literature. Bücher et al. [27] reported that the treatments performed by strictly following the procedure recommended by IADT in patients with TDI 
complaints decrease the risk of developing complications. The high rate of complications despite IADT procedures applied in our treatments may be attributable to the patient not paying attention to restoration after restoration (loss of filling due to biting hard foods or deterioration or discoloration of the surface structure of the restoration due to poor oral hygiene). Restoration success can be increased by informing patients, oral hygiene training, and motivation.

Robertson reported that in patients with crown fractures followed for 15 years, the complication rate increased statistically significantly if the fracture was accompanied by luxation injury [25]. Ravn's [23] study involving 4067 teeth states that the luxation injuries negatively affect the prognosis of the tooth. As consistent with many studies done [19,22,27,29], in this study, it's also found that the complication rate in crown fractures is 2.5 times higher in the presence of luxation. Complications were significantly higher in crown fractures accompanied by luxation for the 6-month, 1-year, and 2-year periods.

Andreasen et al. [20] reported that early or delayed treatment makes no difference in pulpal healing if pulp capping or partial pulpotomy will be performed in the case of crown fractures, but acute and subacute treatment is more successful in the cases of cervical pulpotomy. According to many studies, delayed or early treatment does not have a negative effect on the prognosis of the tooth in the case of crown fractures [21,22,24,30-32]. The success of the treatment is affected by accompanying luxation injuries, whether the pulp is exposed, and how the separation of early-late treatment is made [20]. Although Robertson et al. [22] stated that there was no statistically significant difference between the treatment of exposed dentin in the emergency and delayed periods in terms of complications; Rock et al. [21] reported that the risk of pulp necrosis significantly increases in teeth treated during the period after 3 days. Ravn [24] reported no difference in pulp necrosis, especially in small corner fractures or horizontal fractures, even if uncomplicated crown fractures are never treated. When early treatment in crown fractures for which the presence of luxation was also evaluated was taken 1 day [22] or 5 days [30,31], no statistical difference was found between early treatment and delayed treatment. As in the study of Rock et al. [21], the current study also accepted the treatments performed within the first 3 days after trauma as early treatment, and no statistically significant relationship was found between the time of arrival and the possibility of developing complications. In complicated or uncomplicated fractures, early or late treatment did not affect the possibility of developing complications. The guidelines of IADT also include crown fractures in the subacute and delayed treatment group and specify no need for urgent treatment [32,33]. Especially in the case of uncomplicated fractures, dentine can resist bacterial invasion thanks to hydrostatic pressure in teeth with intact pulpal circulation [34]. According to studies, inflammatory changes in the pulp are temporary, and if there is no concomitant luxation injury, the vascular supply of the pulp remains intact and prevents bacterial invasion [35,36]. Moreover, clinical studies suggest that the pulp has a chance to heal with hard tissue, even if it remains exposed for days or weeks $[32,37]$.

When the effect of post-TDI substance loss in the teeth on the possibility of developing complications was investigated, it was stated that the fracture's localization and closeness to the pulp were important rather than its size $[20,24]$. In the literature, it is reported that small corner fractures or horizontal fractures are not effective in the development of pulp necrosis, but pulp necrosis is more common in fractures involving a large part of the proximal region [20,24]. Ravn [24] reported that necrosis develops more frequently in mesial $(8.9 \%)$ and distal $(11.7 \%)$ fractures in the teeth categorized in the same way as the current study. In the current study, the incidence rate of complications was found to be the highest in proximal fractures, which we call class 4, with $32.8 \%$. The fact that the loss of substance was more or less caused a statistically significant difference in 
the development of complications only in the year-1 controls. Its believed that the reason for this is that the complications, pulp necrosis, arise mainly during the year-1 controls. In the literature, it is reported that pulp necrosis resulting from crown fractures occurs mostly in the first 6-12-month period [27].

Most of the studies assert that open apiced teeth have a high post-traumatic healing capacity and a low rate of complications [19,23-25,38,39]. Andreasen and Andreasen [19] found that the probability of pulp survival in crown fractures accompanied by luxation injuries was $15 \%$ in closed apex teeth but $60 \%$ in open apiced teeth. The compilation prepared by Olsburgh et al. [38] also states that the openness of the apex increases the chance of healing. Like previous studies, we also found that less complication is observed in open apiced teeth in all periods. This may be due to higher pulp blood supply and higher potential for healing in young permanent teeth.

According to the common finding of Andreasen [39] and Barnett [40], the severity and type of trauma, concomitant luxation injury, and the development stage of the tooth are the most important factors in the development of pulp necrosis. As noted in many studies, if an uncomplicated crown fracture is not accompanied by luxation injury, pulpal complication is not expected [41,42]. Bücher et al. [27] reported that luxation injury increases the rate of complications in permanent teeth by 1.5 times. In their study evaluating the luxation injuries by their types, Wang et al. reported that crown fractures accompanied by intrusion increase the incidence rate of pulp necrosis by 33 times [23]. The studies conducted report the incidence of complications related to pulpal healing as $1-3 \%[20,42]$. In complicated crown fractures, the risk of pulp necrosis is higher even though the prognosis varies depending on the fracture location, width of the area where the pulp is exposed, and the accompanying luxation injury [22,25,29]. As consistent with the literature, this study also determined that the type of fracture increases the risk of developing pulp necrosis and the results obtained are statistically significant.

Ravn's [24] study reports that the likelihood of pulp necrosis in uncomplicated fractures varies between $5.8 \%$ and $30.1 \%$, depending on the severity of the luxation injury. Robertson et al. reported that the incidence rate of pulp necrosis in complicated fractures increases from $5 \%$ to $75 \%$ when accompanied by luxation injury [22]. The current study found that the probability of developing pulp necrosis increases statistically significantly in the presence of a luxation injury accompanying the crown fracture. Similarly, in the literature, it is reported that luxation injuries increase pulp necrosis by up to $100 \%[19,23,33,41,42]$. The prevalence may vary depending on the type of luxation, the stage of root development, and the number of dentin tubules exposed $[27,43]$.

In crown fractures involving enamel and dentin, bacteria and their products may invade the exposed dentin canals. According to Ravn [24], since the dentin canals are wider, especially in young permanent teeth, the pulp is affected by bacteria and thermal stimuli more quickly. According to the studies carried out, even if the fracture line does not include the pulp [44,45], the risk of necrosis increases in fractures with a high loss of substance as well as fractures approaching the pulp from the proximal region [24]. This finding is supported by the results obtained in the current study. In the case of substance loss by more than one-third of the crown, the risk of pulp necrosis increases significantly.

It was determined that high loss of substance, completed root development, affected pulp during injury, and brushing frequency less than 1 per day increase the incidence rate of complication, although it is not statistically significant in all periods. The complication development rate was highest (32.8\%) in proximal fractures involving the mesial or distal corner. Although the loss of substance in the proximal is small, these fractures should not be overlooked due to the direction of the dentin tubules but subjected to long-term follow- 
up. The incidence rate of pulse necrosis is statistically significantly increased by the type of fracture, luxation injury, and loss of substance more than 3 units in all periods $(\mathrm{p}<0.05)$.

\section{Conclusion}

Complication incidence increases in direct proportion to time in all follow-up periods. Pulp necrosis, the most common complication, was observed by $21.6 \%$ in year 2 in crown fractures. For this reason, it would be beneficial to strictly follow the guidelines of IADT and to subject the crown fractures to long-term followup. Knowing the factors that may be effective in the development of complications in crown fractures, which is the most common type of trauma, will ensure that precautions are taken to avoid traumatic injury. Long-term follow-up of developing complications will shed light on a more effective and quality treatment in the future. In light of these results, it was shown that the regular at least 2-year follow-up of crown fractures in children is important in terms of early detection and intervention of complications.

\section{Authors' Contributions}

\begin{tabular}{|c|c|c|}
\hline & (D) https://orcid.org/0000-0003-2030-5429 & $\begin{array}{l}\text { Conceptualization, Methodology, Formal Analysis, Investigation, Data Curation, Writing - } \\
\text { Original Draft, Writing - Review and Editing and Project Administration. }\end{array}$ \\
\hline $\mathrm{EZ}$ & (iD) https://orcid.org/0000-0003-0746-7087 & $\begin{array}{l}\text { Conceptualization, Methodology, Investigation, Data Curation, Writing - Review and Editing, } \\
\text { Visualization, Supervision and Project Administration. }\end{array}$ \\
\hline MSB & (i) https://orcid.org/0000-0002-5719-5430 & Conceptualization, Methodology, Investigation, Writing - Review and Editing and Supervision. \\
\hline
\end{tabular}

\section{Financial Support}

None.

\section{Conflict of Interest}

The authors declare no conflicts of interest.

\section{Data Availability}

The data used to support the findings of this study can be made available upon request to the corresponding author.

\section{Acknowledgments}

We would like to thank Prof. Dr. Çiğdem Guler who helped us as a consultant in the patients treated within the scope of this study.

\section{References}

[1] Altay N, Güngör HC. A retrospective study of dentoalveolar injuries of children in Ankara, Turkey. Dent Traumatol 2001; 17(5):201-4. https://doi.org/10.1034/j.1600-9657.2001.170502.x

[Q] Andreasen FM, Ravn JJ. Epidemiology of traumatic dental injuries to primaly and permanent teeth in a Dannish population sample. Int. J Oral Surg 1972; 1(23):5-9. https://doi.org/10.1016/s0300-9785(72)80042-5

[3] Borssen E, Holm AK. Traumatic dental injuries in a cöhort of 16-year-old in northen Svveden. Endod Dent Traumatol 1997; 13(6):276-80. https://doi.org/10.1111/j.1600-9657.1997.tb00055.x

[4] Caldas AF, Burgos MEA. A retrospective study of traumatic dental injuries in a Brazilian dental trauma clinic. Dent Traumatol 2001; 17(6):250-3. https://doi.org/10.1034/j.1600-9657.2001.170602.x

[5] Çalışkan MK, Turkun M. Clinical invesatigation of traumatic injuries of permanent incisors in Izmir, Turkey. Endod Dent Traumatol 1995; 11(5):210-3. https://doi.org/10.1111/j.1600-9657.1995.tbo0490.x

[6] Gabris K, Tarjan I, Rozsa N. Dental trauma in children presenting for treatment at the Department of Dentistry for Children and Orthodontics, Budapest. Dent Traumatol 2001; 17(3):103-8. https://doi.org/10.1034/j.1600-9657.2001.017003103.x

[7] Agostini FG, Flaitz CM, Hicks MJ. Dental emergencies in a university-based pediatric dentistry postgraduate outpatient clinic: a retrospective study. ASDC J Dent Child 2001; 68(5-6):300-11,316-21. 
[8] Fleming P, Gregg TA, Saunders ID. Analysis of an emergency dental service provided at a children's hospital. Int J Paediatr Dent 1991; 1(1):25-30. https://doi.org/10.1111/j.1365-263x.1991.tb00317.x

[9] Lombardi S, Sheller B, Williams BJ. Diagnosis and treatment of dental trauma in a children's hospital. Pediatr Dent 1998; 20(2):112-20.

[10] Quinby DJ, Sheller B, Williams BJ, Grembowski D. Parent satisfaction with emergency dental treatment at a children's hospital. J Dent Child 2004; 71(1):17-23.

[11] Sheller B, Williams BJ, Lombardi SM. Diagnosis and treatment of dental caries-related emergencies in a children's hospital. Pediatr Dent 1997; 19(8):470-5.

[12] Von Kaenel D, Vitangeli D, Casamassimo PS, Wilson S, Preisch J. Social factors associated with pediatric emergency department visits for caries-related dental pain. Pediatr Dent 2001; 23(1):56-60.

[13] Al-Jundi SH. Dental emergencies presenting to a dental teaching hospital due to complications from traumatic dental injuries. Dent Traumatol 2002; 18(4):181-5. https://doi.org/10.1034/j.1600-9657.2002.02081.x

[14] Odabaş ME, Deveci C, Alaçam A. Çocuk hastalarda acil diş tedavilerinin retrospektif değerlendirilmesi. GÜ Diş Hek Fak Derg 2012; 29(1):7-10. [ In Turkish].

[15] Unal M, Oznurhan F, Kapdan A, Aksoy S, Dürer A. Traumatic dental injuries in children. Experience of a hospital in the central Anatolia region of Turkey. Eur J Paediatr Dent 2014; 15(1):17-22.

[16] Marcenes W, al Beiruti N, Tayfour D, Issa S. Epidemiology of traumatic injuries to the permanent incisors of 9-12year old school children in Damascus, Syria. Endod Dent Traumatol 1999; 15(3):117-23. https://doi.org/10.1111/j.1600-9657.1999.tbo0767.x

[17] Andreasen JO. Challenges in clinical dental traumatology. Endod Dent Traumatol 1985; 1(2):45-55. https://doi.org/1010.1111/j.1600-9657.1985.tb00560.x

[18] Cavalleri G, Zerman N. Traumatic crown fractures in permanent incisors with immature roots: a follow-up study. Endod Dent Traumatol 1995; 11:294-6. https://doi.org/10.1111/j.1600-9657.1995.tbo0507.x.

[19] Andreasen JO, Andreasen FM. Textbook and Color Atlas of Traumatic Injuries to the Teeth. Munksgaard: Copenhagen; 1994.

[20] Andreasen JO, Andreasen FM, Skeie A, Hjorting-Hansen E, Schwartz O. Effect of treatment delay upon pulp and periodontal healing of traumatic dental injuries, a review article. Dent Traumatol 2002; 18(3):116-28. https://doi.org/10.1034/j.1600-9657.2002.00079.x.

[21] Rock WP, Gordon PH, Friend LA, Grundy MC. The relationship between trauma and pulp death in incisor teeth. Br Dent J 1974; 136(6):236-9. https://doi.org/10.1038/sj.bdj.4803162

[22] Robertson A, Andreasen FM, Andreasen JO, Noren JG. Long-term prognosis of crown-fractured permanent incisors. The effect of stage of root development and associated luxation injury. Int J Paediatric Dent 2000; 10(3):191-9. https://doi.org/10.1046/j.1365-263x.2000.00191.x

[23] Wang C, Qin M, Guan Y. Analysis of pulp prognosis in 603 permanent teeth with uncomplicated crown fracture with or without luxation. Dent Traumatol 2014; 30(5):333-7. https://doi.org/10.1111/edt.12099

[24] Ravn JJ. Follow-up study of permanent incisorswith enamel dentin fractures after acute trauma. Scand J Dent Res 1981; 89(5):355-65. https://doi.org/10.1111/j.1600-0722.1981.tb01694.x

[25] Robertson, A. A retrospective evaluation of patients with uncomplicated crown fractures and luxation injuries. Endod Dent Traumatol 1998; 14(6):245-56. https://doi.org/10.1111/j.1600-9657.1998.tbo0848.x

[26] Sandalli N, Cildir SK, Guler N. Clinical investigation of traumatic injuries in Yeditepe University during the last 3 years. Dent Traumatol 2005; 21(4):188-94. https://doi.org/10.1111/j.1600-9657.2005.00309.x

[27] Bücher K, Neumann C, Thiering E, Hickel R, Kühnisch J; International Association of Dental Traumatology. Complications and survival rates of teeth after dental trauma over a 5-year period. Clin Oral Investig 2013; 17(5):1311-8. https://doi.org/10.1007/s00784-012-0817-y

[28] Petrovic B, Marković D, Peric T, Blagojevic D. Factors related to treatment and outcomes of avulsed teeth. Dent Traumatol 2010; 26(1):52-9. https://doi.org/10.1111/j.1600-9657.2009.00836.x

[29] Hecova H, Tzigkounakis V, Merglova V, Netolicky J. A retrospective study of 889 injured permanent teeth. Dent Traumatol 2010; 26(6):466-75. https://doi.org/10.1111/j.1600-9657.2010.00924.x

[30] Fuks AB, Bielak S, Chosak A. Clinical and radiographic assessment of direct pulp capping and pulpotomy in young permanent teeth. Pediatr Dent 1982; 4(3):240-4.

[31] Cvek M. Partial pulpotomy in crown-fractured incisors-results 3 to 15 years after treatment. Acta Stomatol Croat 1993; 27:167-73.

[32] Andreasen JO, Bakland LK, Flores MT, Andreasen FM, Andersson L. Travmatik Dental Yaralanmalar el Kitabı. Eden E, Translation Editor. İstanbul: Elma Basım; 2014. [In Turkish].

[33] Diangelis AJ, Andreasen JO, Ebeleseder KA, Kenny DJ, Trope M, Sigurdsson A, et al. International Association of Dental Traumatology guidelines for the management of traumatic dental injuries: 1. Fractures and luxations of permanent teeth. Dent Traumatol 2012; 28(1):2-12. https://doi.org/10.1111/j.1600-9657.2011.01103.x

[34] Hörsted PB, Simonsen AM, Larsen MJ. Monkey pulp reactions to restorative materials. Scand J Dent Res 1986; 94(2):154-63. https://doi.org/10.1111/j.1600-0722.1986.tbo1380.x 
[35] Mjör IA, Tronstad L. The healing of experimentally induced pulpitis. Oral Surg Oral Med Oral Pathol 1974; 38(1):115-2 1. https://doi.org/10.1016/0030-4220(74)90322-3

[36] Warfvinge J, Bergenholtz G. Healing capacity of human and monkey dental pulps following experimentally-induced pulpitis. Endod Dent Traumatol 1986; 2(6):256-62. https://doi.org/10.1111/j.1600-9657.1986.tbo0158.x

[37] Cvek M. Endodontic Management and the Use of Calcium Hydroxide in Traumatized Permanent Teeth. In: Andreasen JO, Andreasen FM, Andersson L, eds. Textbook and Color Atlas of Traumatic Injuries to the Teeth. Oxford: Blackwell; 2007. p. 598-658.

[38] Olsburgh S, Jacoby T, Krejci I. Crown fractures in the permanent dentition: pulpal and restorative considerations. Dent Traumatol 2002; 18(3):103-15. https://doi.org/10.1034/j.1600-9657.2002.00004.x

[39] Andreasen FM. Histological and bacteriological study of pulps extirpated after luxation injuries. Endod Dent Traumatol 1988; 4(4):170-81. https://doi.org/10.1111/j.1600-9657.1988.tb00317.x

[40] Barnett F. The role of endodontics in the treatment of luxated permanent teeth. Dent Traumatol 2002; 18(2):47-56. https://doi.org/10.1034/j.1600-9657.2002.00098.x

[41] Andreasen JO, Andreasen FM, Bakland LK, Flores MT. Traumatic Dental Injuries: A manual. Copenhagen: Munksgaard; 2003. p. 8-71.

[42] Andreasen FM, Andreasen JO. Crown Fractures. In: Andreasen JO, Andreasen FM, Andersson L. eds. Textbook and Color Atlas of Traumatic Injuries to the Teeth. Oxford: Blackwell; 2007. p. 280-305.

[43] Andreasen FM, Vestergaard PB. Prognosis of luxated permanent teeth-the development of pulp necrosis. Endod Dent Traumatol 1985; 1(6):207-20. https://doi.org/10.1111/j.1600-9657.1985.tbo0583.x

[44] Herforth A. Zur Frage der Pulpavitatitat nach Frontzahntrauma bei Jugendlichen-eine Longitudinalentersucheng. Dtsch Zahnarztl Z 1976; 31:938-46. [In Germany].

[45] Stalhane I, Hedegard B. Traumatized teeth in children aged 7-15 years. Part II. Swed Dent J 1975; 68(5):157-69. 